\title{
Analysis of Export Competitiveness of Natural Rubber from Indonesia and Thailand in the International Market
}

\author{
Mustafa Usman ${ }^{1}$, Mita Rezekina $\mathrm{U}^{2}$, Akhmad Baihaqi ${ }^{3}$, Srihandayani ${ }^{4}$ \\ 1,2,3Agribusiness Department, Universitas Syiah Kuala, Banda Aceh, Indonesia \\ ${ }^{4}$ Agribusiness Departemen, Universitas Teuku Umar, Meulaboh, Indonesia \\ Email: musthafa.koti@gmail.com; mitarezekina14@gmail.com; baihaqi@unsyiah.ac.id; \\ Srihandayani@utu.ac.id
}

\section{Abstract:}

Natural rubber is one of the commodities that plays an important role as a foreign exchange earner. This study aims to determine how the competitiveness of natural rubber in Indonesia and Thailand as the main producers in the world market. The data used in this study is the volume of exports and imports of natural rubber in Indonesia and Thailand for 15 years in the 2004-2018 period. This research uses Revealed Comparative Advantage (RCA) analysis to analyze comparative advantage and Trade Specialization Index (ISP) to analyze competitive advantage. The RCA analysis results in world markets, the United States market and the Chinese market show a number of more than 1 which means that natural rubber in Indonesia and Thailand have strong competitiveness or comparative advantage. However, in the world market and the United States market the value of the Indonesian natural rubber RCA index is higher than the Thai RCA index value so that the competitiveness of Indonesia's natural rubber is stronger than Thailand, while in the Chinese market the value of the Thai RCA index is the opposite. Indonesia and Thailand ISP Index values show positive results, indicate that these two countries have a tendency to be an exporter of natural rubber commodity in the world market, the American market, and the Chinese market.

Keywords:

competitiveness; natural rubber; RCA; ISP

\section{Introduction}

The export performance of a country depends on the competitiveness of exported products in world markets. A country that is able to increase its competitiveness will have greater opportunities to expand the market both domestically and internationally. Indonesian agricultural sector, especially the agriculture subsector, with one of its leading export commodities, natural rubber, continues to show export capabilities to compete in international markets (Permatasari, 2015). According to the Ministry of Industry and Trade (1999) Natural rubber plays an important role as a foreign exchange earner, where natural rubber is a non-oil and gas export commodity which shows significant developments every year. This commodity is also able to create job opportunities as well as improve the welfare of the community in the production processing process.

About $93 \%$ of natural rubber is produced mainly in Southeast Asia, where Indonesia is the second largest producing country in the world after Thailand. Indonesia and Thailand continue to compete in producing natural rubber. According to the Food and Agliculture Organization (2019) in 2018 Thailand is the largest natural rubber producer in the world with an average production of 4 million tons per year then the second position is occupied by Indonesia with an average production of 3 million tons per year, third to sixth positions 
Economit Journal: Scientific Journal of Accountancy, Management and Finance ISSN: 2775-5827 (Online), 2775-5819 (Print)

Vol. 1, No. 4, November 2021, Page: 220-230

Email: economitjournal@gmail.com

occupied by Vietnam, India, China and Malaysia respectively. The two main world natural rubber producing countries, namely Thailand and Indonesia, have different export destination countries or in other words have different market shares (Sinaga, 2011). According to the Ministry of Trade (2006), Indonesia has a major export destination country to the United States of America, which is around $32.32 \%$. On the other hand, so far about $70 \%$ of China's natural rubber needs have been met or supplied by Thailand.

China is the largest importer country in the world with imports reaching 2.5 million tons followed by the United States with 997 thousand tons per year. World rubber demand mainly comes from automotive industrial countries such as China, the United States, Japan and other countries. The increasing world use of natural rubber provides a huge opportunity for Indonesia to increase its export potential. According to the Ministry of Industry (2009), Indonesia has the advantage of increasing its natural rubber production in the future, namely by still providing sufficiently large tropical land suitable for planting rubber trees. Indonesia is a country with the largest natural rubber plantation area in the world, with a total area of 3.65 million hectares or about half the size of Thailand's natural rubber plantations. However, this does not make Indonesia the largest rubber exporting country (Syahputra, 2014). The main problem with the development of natural rubber in Indonesia is that the level of land productivity is still low and the quality of the rubber produced is also unsatisfactory. When compared to Thailand, the level of productivity of Indonesia's land, especially smallholder plantations, has only reached 0.9 tonnes / ha / year, while the productivity of Thailand's natural rubber lands has reached 1.4 tonnes / ha / year (FAO), 2019).

The increasing demand for natural rubber in the world and the intense competition for natural rubber commodities between Indonesia and competing countries, especially Thailand, shows that an increase in competitiveness is needed to keep Indonesian natural rubber able to continue to compete in the international market. The purpose of this research is to find out how the competitiveness of Indonesian natural rubber and Thai natural rubber in the world market, in the United States market as the main export destination country for Indonesian rubber exports and in the Chinese market as the main export destination country for Thai natural rubber exports.

\section{Research Methods}

This research uses quantitative methods with secondary data in the form of time series data from 2004-2018. Data sources were obtained from several related agencies, such as the Directorate General of Plantations, Badan Pusat Statistik (BPS), the Food and Agriculture Organization (FAO), Trade Map, UN Comtrade as well as various literature, theses, text books, journals, and related internet articles with this research. The variables used in this study are; The total value of world natural rubber exports; The total value of world natural rubber exports; The total export value of all world commodities; The total export value of all commodities; Export value of natural rubber from Indonesia and Thailand; and Import value of natural rubber from Indonesia and Thailand. The analytical methods used are Revealed Comparative Advantage (RCA) to analyze comparative advantage and Trade Specialization Index to analyze competitive advantage. The tool used is Microsoft Excel 2010. 


\subsection{Revealed Comparative Advantage}

RCA describes the appearance of natural rubber exports, which is the ratio between a country's shares of natural rubber exports to the share of world natural rubber exports. The Revealed Comparative Advantage (RCA) indicator is that if the export of natural rubber from Indonesia or Thailand is more than the share of natural rubber in total world exports, then the two countries have a comparative advantage for the production and export of natural rubber, and vice versa. Mathematically, the RCA index known as Balassa Index is formulated as follows:

$$
\mathrm{RCA}=\frac{X i j / X_{j j}}{X i w / X_{w w}}
$$

Where, $\mathrm{Xij}$ is export value of country $\mathrm{j}$ 's natural rubber (US \$), $\mathrm{Xj}$ is the total export value of country $\mathrm{j}$ (US \$), Xiw is world natural rubber export value (US \$), Xw is total value of world exports (US \$), $j$ is Indonesia or Thailand. The criteria for decision making on the RCA value, namely, if the RCA index for natural rubber exports is more than 1 (RCA> 1), it means that the country's natural rubber exports have a comparative advantage over the world average. Vice versa, if the RCA index of natural rubber exports is less than 1 (RCA <1), it means that the country's natural rubber exports have lower competitiveness than the world average. The greater the index value, the higher the level of comparative advantage (Tambunan, 2001).

\subsection{Trade Specialization Index (ISP)}

The Trade Specialization Index is a general method used as a measure of the level of competitiveness of a commodity in which natural rubber is used in this study. ISP analyzes the position or stages of natural rubber development by describing whether for natural rubber, the positions of Indonesia and Thailand tend to be exporters or importers. Mathematically, this index can be formulated as follows:

$$
\text { ISP }=\frac{[X i a-M i a j)}{[X i a+M i a j]}
$$

Where ISP is index analyzes the position of country a for natural rubber commodity, $\mathrm{X}$ ia is export value of natural rubber in country a (US \$), $\mathrm{M}$ ia is an import value of natural rubber in country a (US \$), ana a is wether Indonesia or Thailand. There are decision-making criteria for the analysis of the Trade Specialization Index, namely if the value indicates a positive numbe $\mathrm{r}$ (above 0-1), then the competitiveness of natural rubber is high and the country in question tends to become an exporter. Conversely, if the Trade Specialization Index value is negative (below 0 to -1 ), then the competitiveness of natural rubber is weak and the country in question tends to act as an importer.

\section{Discussion}

\subsection{Results}

a. Development of Indonesian Natural Rubber

Table 1. Development of Production, Domestic Demand, Export and Import of Indonesian Natural Rubber in Tonnes 2004-2018

\begin{tabular}{rrrrr}
\hline Year & Production (ton) & Export (ton) & Import (ton ) & Domestic Demand (Ton) \\
\hline 2004 & 2.065 .820 & 1.875 .059 & 7.502 & 198.263 \\
2005 & 2.270 .891 & 2.024 .608 & 6.592 & 252.875 \\
2006 & 2.637 .231 & 2.287 .053 & 6.874 & 357.052 \\
\hline
\end{tabular}




\begin{tabular}{lrrrr}
\hline 2007 & 2.755 .172 & 2.407 .848 & 9.830 & 357.154 \\
2008 & 2.751 .286 & 2.296 .475 & 13.058 & 467.869 \\
2009 & 2.440 .347 & 1.992 .001 & 13.024 & 461.370 \\
2010 & 2.734 .900 & 2.352 .775 & 17.189 & 399.314 \\
2011 & 2.990 .200 & 2.557 .093 & 16.668 & 449.775 \\
2012 & 3.012 .254 & 2.445 .666 & 27.174 & 593.762 \\
2013 & 3.107 .544 & 2.703 .287 & 24.585 & 428.842 \\
2014 & 3.153 .186 & 2.623 .471 & 28.917 & 558.632 \\
2015 & 3.145 .398 & 2.631 .139 & 33.541 & 547.800 \\
2016 & 3.307 .142 & 2.579 .124 & 30.311 & 758.329 \\
2017 & 3.629 .544 & 2.994 .981 & 30.233 & 664.796 \\
2018 & 3.630 .268 & 2.812 .686 & 46.959 & 864.541 \\
\hline
\end{tabular}

* Domestic Demand $=$ Production - Export + Import

Source: UN Comtrade and FAO, 2019

Table 1 shows that Indonesia's natural rubber production continued to increase steadily from 2004 to 2018 with the average of growth rate is $0,037 \%$. According to Harahap (2018) the low productivity of Indonesia's natural rubber per hectare is due to old trees as well as the low investment ability of small farmers thereby reducing yields which in turn results in the least amount of production. About $85 \%$ of the production is allocated for export activities. Based on BPS data (2011), in 2010, Indonesia's natural rubber exports contributed $5.94 \%$ of total national exports. The volume of natural rubber imports to Indonesia continues to increase from year to year in relatively small amounts and is limited in the form of concentrated latex which is needed by the domestic latex finished goods industry. Domestic demand for rubber during 2004-2018 was very volatile and tended to increase with an average increase of $13.3 \%$. This increase indicates a change in Indonesia's manufacturing industry which is getting better despite the slow growth.

\section{b. Development of Thailand Natural Rubber Market}

Table 2. Development of Production, Domestic Demand, Export and Import of Indonesian Natural Rubber in Tonnes 2004-2018

\begin{tabular}{rrrrr}
\hline Year & Produksi (ton) & Ekspor (Ton) & Impor (Ton) & $\begin{array}{c}\text { Permintaan Domestik } \\
\text { (Ton) }\end{array}$ \\
\hline 2004 & 2.984 .293 & 2.637 .096 & 1.601 & 348.798 \\
2005 & 2.937 .158 & 2.632 .398 & 1.584 & 306.344 \\
2006 & 3.136 .993 & 2.771 .673 & 1.273 & 366.593 \\
2007 & 3.056 .005 & 2.703 .762 & 1.911 & 354.154 \\
2008 & 3.089 .751 & 2.675 .283 & 4.458 & 418.926 \\
2009 & 3.164 .379 & 2.738 .584 & 3.166 & 428.961 \\
2010 & 3.252 .135 & 2.733 .607 & 6.541 & 525.069 \\
2011 & 3.569 .033 & 2.997 .018 & 4.398 & 576.413 \\
2012 & 3.778 .010 & 2.998 .866 & 3.239 & 782.383 \\
2013 & 4.170 .428 & 3.437 .042 & 2.606 & 735.992 \\
2014 & 4.323 .975 & 3.409 .387 & 4.108 & 918.696 \\
2015 & 4.473 .433 & 3.653 .496 & 5.583 & 825.520 \\
2016 & 4.536 .965 & 3.492 .970 & 3.683 & 1.047 .678 \\
2017 & 4.600 .000 & 3.665 .067 & 2.663 & 937.596 \\
2018 & 4.744 .250 & 3.525 .969 & 1.608 & 1.219 .889 \\
\hline
\end{tabular}

* Domestic Demand $=$ Production - Export + Import

Source: UN Comtrade and RRIT. 2019 
Thailand is the largest natural rubber producer in the world, producing around 3-4 million tonnes of natural rubber per year (RRIT, 2019). It can be seen in Table 2 that Thailand's natural rubber production conditions tend to increase from year to year with an average growth rate of $0,031 \%$. Thailand is the world's largest exporter of natural rubber and has a $36.8 \%$ share of the global export market valued at US $\$ 12$ billion per year. Based on UK Essays (2018) nearly $90 \%$ of Thailand's natural rubber production is for export activities, only $10 \%$ is for domestic use. The highest import volume occurred in 2010, amounting to 6 thousand tons, while the lowest import volume occurred in 2006, which only imported one thousand tons (UN Comtrade, 2019). Quoted from Thailand Investment Review (2016) as the world's largest natural rubber producer, several international rubber product companies such as Bridgestone, Dunlop, Durex and other companies set up manufacturing bases in Thailand. The presence of these companies causes domestic consumption to continue to increase every year, even reaching 1.2 million tons in 2018.

\section{c. Competitiveness of Indonesian and Thai Natural Rubber in the World Market}

The use or consumption of natural rubber continues to increase from year to year. According to IRSG data, in 2007 the world consumption of natural rubber was 10.2 million tons and this volume increased in 2008 to 10.8 million tons. It is known that in 2014 the total world consumption of natural rubber has reached 11.86 million tons. Based on data from the Rubber Statistical Bulletin (2018), it shows that world consumption of natural rubber increased by $8,937 \%$ during $2015-2017$. This increase was partly due to the development of automotive industrial countries such as China and the United States. Indonesia and Thailand, as the largest producers and exporters of natural rubber, play a large role in supplying the world's natural rubber needs. Following are the results of the analysis of the Revealed Comparative Advantage (RCA) and the Trade Specialization Index (ISP) in world markets.

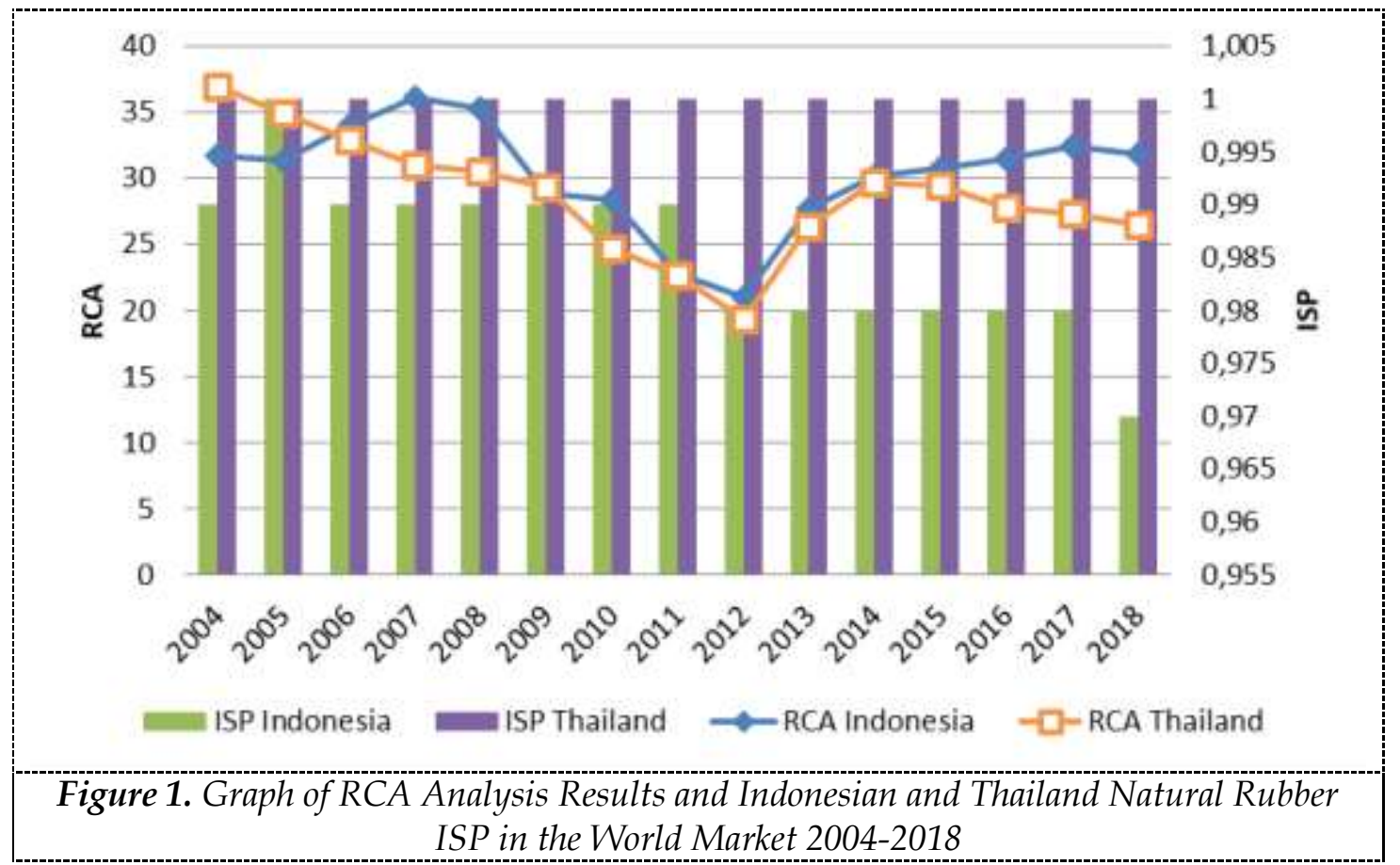

The RCA index values both in Indonesia and Thailand continued to flutuate over the 15-year perioed 2004-2018. According to Ratnawati (2011) in 2009, the RCA index value for Indonesia and Thailand experienced a decline as a result of the global crisis in the third quarter of 2008 which weakened the automotive industry as the main basis for the natural rubber 
industry so that world demand for natural rubber declined. Not only quantity, but the value of world natural rubber exports also decreased by $40.24 \%$. The decline in the export value of natural rubber occurred due to the decline in natural rubber prices from US $\$ 2,493$ / ton to US $\$ 1,595 /$ ton.

The average RCA index value for Indonesian and Thai natural rubber on the world market from 2004 to 2018 is 30.2 and 28.6, respectively. These two values are greater than 1 $(\mathrm{RCA}>1)$ which means that both Indonesian and Thai natural rubber have a comparative advantage over the world average competitiveness for natural rubber commodities, however Indonesia has stronger competitiveness due to the high share of natural rubber exports, which was $30.2 \%$, while the export share of Thai natural rubber in the world was 28.6. The average value of Indonesian and Thai ISPs for natural rubber was 0.99 and 1, respectively. This figure is between 0 and +1 , meaning that the natural rubber commodities of Indonesia and Thailand have fairly strong competitiveness and these two countries tend to act as exporters of natural rubber commodities in the world market with Thailand having a stronger competitive advantage than Indonesia.

According to the research of Radityo, et al (2014) from 1991 to 2006 Thailand take a charge the market share of natural rubber, then Indonesia shifted the market share of Thailand from 2006 to 2011 with the highest market share in 2007 to 2009 at 38\% of total exports natural rubber in the world market. Other research conducted by Syahputra, et al (2014), Thailand is relatively superior to Indonesia in the comparative advantage of its natural rubber exports for the period 1996-2006, which is indicated by the lower Indonesian RCA value than Thailand, but then the Thai index value began to decline. This situation is due to the increasing domestic rubber consumption of Thailand and the not yet optimal production of the rubber land which has just been revitalized, making the export value of Thai natural rubber in 2006 experiencing a smaller growth, namely 46.5\% compared to Indonesia's $67.1 \%$. In addition, the growth of world natural rubber exports was also higher than Thailand's, namely $52 \%$, so this value then affected the export performance of Thailand's natural rubber.

The increase that occurred in Indonesia's RCA index value was due to the improvement in the export performance of natural rubber due to the increase in planted area every year by improving the planting system that used superior clones so that the increase in productivity was getting better. This increase is in line with the target of the Indonesian government, where in 2025 Indonesia will become the largest natural rubber exporter (Rochmat, 2017). In addition, the existence of a guaranteed trade relationship between ASEAN and China through the ACFTA which began in 2004 has a good impact on natural rubber exports in Indonesia (Widyantari, 2013). So far, Indonesia's exports have relied on factors of comparative advantage as the main determinant of its competitiveness, especially price competitiveness, such as cheap labor wages and abundant natural resources so that procurement costs are low (Trade Map, 2019).

The ISP value is the ratio between the total trade in natural rubber and the total trade in natural rubber in Indonesia and Thailand. It can be seen in the graph that the value of Indonesian ISPs varies more than the value of Thai ISPs where for 15 years, from 2004 to 2018, it shows the same number, namely 1. Starting from 2006 to 2011, the value of Indonesian ISPs decreased by 0.01 points from the previous value of 1 to 0.99 . The ISP value decreased again in 2012 to 2017, namely the value of 0.98 , then it decreased again in 2018, namely to 0.97 . The decline was due to an increase in the number of rubber imports by Indonesia. In 2018, Indonesia imported 46,959 tons of natural rubber or US \$52 million, while 
in that year the export value of Indonesian natural rubber was decreasing, namely US \$3.9 billion from the previous year which was valued at US $\$ 5.1$ billion (Juliyanto, 2009).

\section{d. Competitiveness of Indonesian and Thai Natural Rubber in the US Market}

Most of Indonesia's natural rubber products are exported to the United States. Based on data from the Central Statistics Agency (BPS), Indonesia's export volume of crumb rubber throughout 2016 reached 2.49 million tons, of which 22.8\% was 568 thousand tons exported to the United States with a value of US \$ 729.2 billion. The United States is one of the world's largest importers of natural rubber. The United States is also the largest synthetic rubber producing country in the world. Although the United States produces synthetic rubber, this country also imports natural rubber due to the large industrial sector consumption of rubber. Exports of natural rubber are needed by the automotive and tire industries in the United States as the main raw material. In addition to the automotive and tire industry sectors, industries in the United States that require rubber as the main material are manufacturing, electronics and mining (Sinaga, 2011).

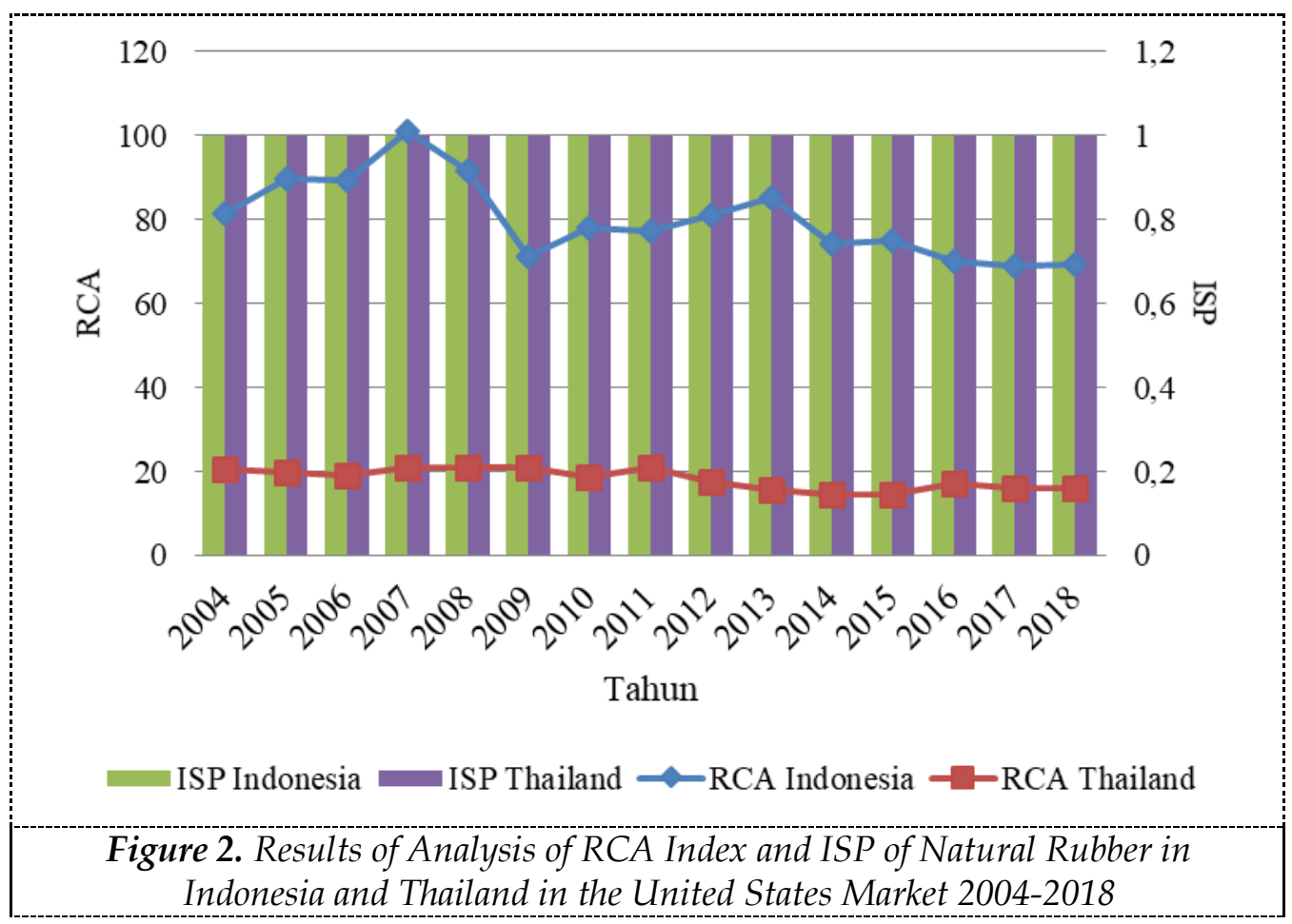

The results of the calculation of the RCA index value for Indonesian and Thai natural rubber which is shown by the line graph have an average value of 80.3 for Indonesia, while the RCA index value for Thailand in the American market is only 18.2. These results show that Indonesia and Thailand have a comparative advantage for natural rubber commodity because they have an RCA value greater than one $(\mathrm{RCA}>1)$. However, Indonesian natural rubber has stronger competitiveness with an $80.3 \%$ export share in the US market compared to Thailand only $18.2 \%$. The results of the calculation of the Trade Specialization Index (ISP) value shown through the bar chart have a constant value of 1, so that both Indonesian and Thai natural rubber have a competitive advantage and these two countries tend to act as exporters of natural rubber commodities in the US market.

According to Choiruddin (2018) the high value of Indonesia's RCA index in the United States market is in line with the greater supply of Indonesian natural rubber 
commodity exports to the United States compared to Thailand. Sinaga (2007) states that over the years Indonesia has continuously exported its natural rubber to the United States of America in large quantities, thus making the United States the main market for Indonesia's natural rubber export activities. Sourced from the UN Comtrade, the export value of Indonesian natural rubber to the United States reached 2 billion USD in 2011 and in the same year Thailand only exported 1 billion USD to the United States. The lower price of Indonesian natural rubber than Thai natural rubber makes Indonesian natural rubber more demanded by natural rubber importing countries such as the United States and Japan (CNBC, 2019).

\section{e. Competitiveness of Indonesian and Thai Natural Rubber in the Chinese Market}

The biggest rubber market is China, where China occupies the first position as the country with the largest rubber consumption of natural rubber and synthetic rubber in the world (CNBC, 2019). In 2017, China consumed 5.39 million tons of natural rubber, reaching $40 \%$ of total world consumption (Ragimun, 2017). The large increase in the use of natural rubber in China was not matched by an increase in the production of its own country, causing China to import natural rubber from other countries in large quantities. Exports of rubber and products from Indonesian rubber to China a quarter of the total exports of Indonesian rubber and rubber products to the world.

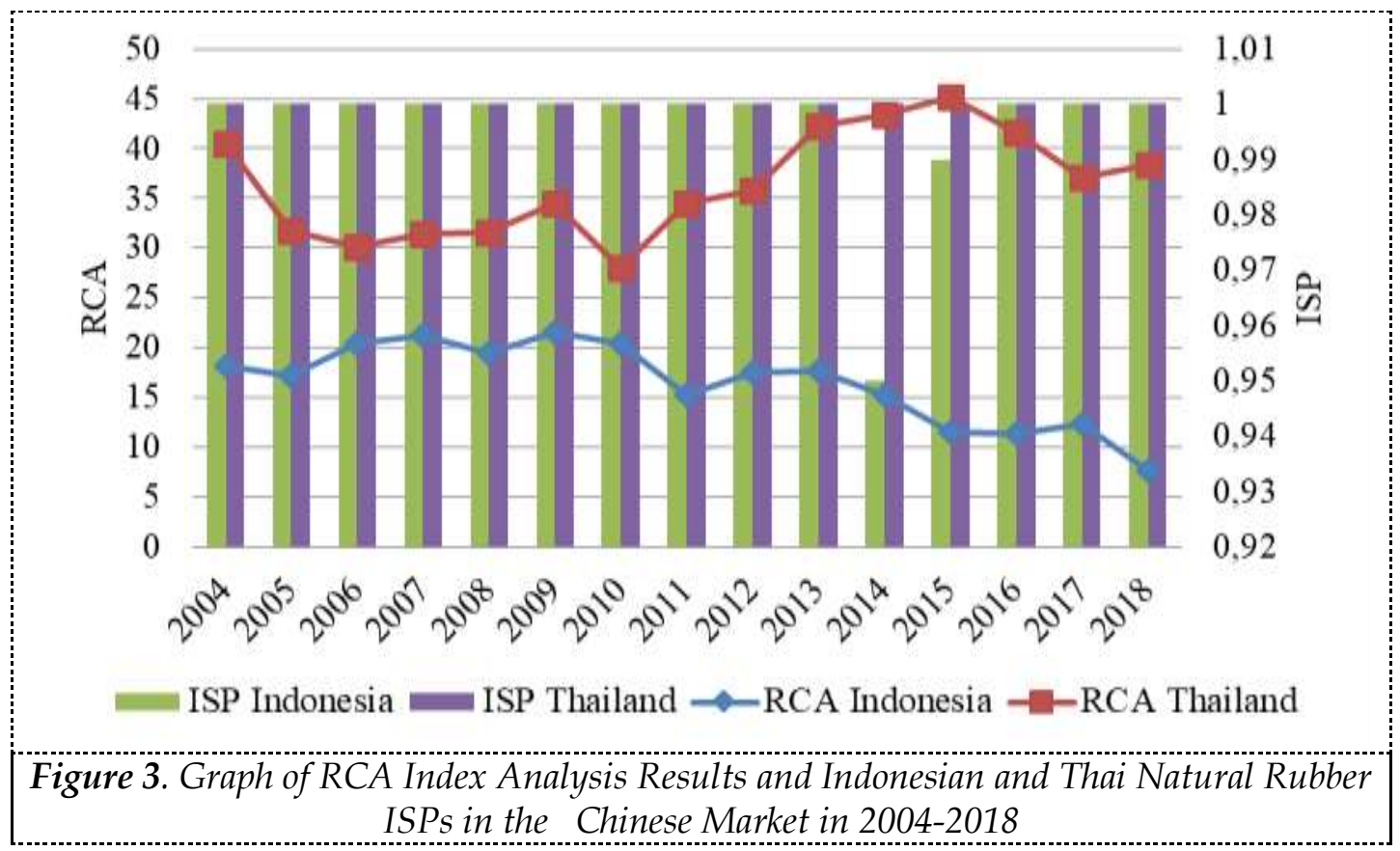

The calculation result of the RCA index value are shown by a line graph and the ISP values are shown in a bar chart. The graph indicates the RCA value is above 1 (RCA>1) and the ISP has a value between 0 and +1 , so that implies Indonesian and Thai natural rubber have a comparative and competitive advantage in the Chinese market in the 2004-2018 period. The average value of Thailand's natural rubber RCA index is higher, namely 36.4 compared to the RCA index value for Indonesian natural rubber which has a value of 16.5, thus Thailand has a stronger competitiveness than Indonesia by controlling $36.4 \%$ of the export market share. China for natural rubber commodity, where Indonesia only $16.5 \%$. The average value of Indonesian and Thai natural rubber ISPs is 1, meaning that both countries act as exporters of natural rubber in the Chinese market. 
China is the main market for Thai natural rubber exports so that the RCA index value for Thai natural rubber in the Chinese market is twice the value of Indonesia's RCA index. Based on the calculation results, Thailand's lowest RCA index value occurred in 2010, namely 28.1, while the highest was in 2015. This high value was due to Thailand supplying $64 \%$ or 2.5 billion USD of total natural rubber imports in 2015. Conducted by China from around the world so that it has an RCA index value of 45.2. The highest Indonesian RCA index value occurred in 2009, namely 21.6, then this value continued to decline until in 2018 the RCA index value was at its lowest point of 7.7. The low value of Indonesia's RCA index in 2018 was due to the high total value of all commodities exported by Indonesia, while the export value of natural rubber was low in result the competitiveness of Indonesian natural rubber in the relevant year was weak. On 2015 China implements standard improvement policy in rubber sheet imports, whereas the quality of Indonesian rubber sheets is still lacking. In 2013, Indonesia's natural rubber exports were valued at US $\$ 1.3$ billion, subsequently this value decreased by $54 \%$ in 2018 to US \$ 353 million. Although the export of natural rubber has decreased, the export of other commodities has increased.

Figure 3 represents the value of Thai ISPs is constant at a value of 1, whreas the value of Indonesian ISPs has experienced a steep decline of 4.5\% in 2014, in result that the value of ISP in the previous year 1 became 0.95. This decline was caused by the low value of Indonesia's exports to China, while the value of natural rubber imports from China in that year was high [12]. The value of ISP is influenced by the value of exports and imports made by Indonesia. Indonesia imports natural rubber from China in relatively small quantities compared to its export value, however there is a tendency for imports to continue to increase from year to year, especially products from Chinese rubber which have relatively cheap prices (Badn Pusat Statistik, 2019).

\subsection{Discussion}

\section{a. Theoretical Contribution}

The increase in the level of competitiveness of Indonesia's natural rubber exports is supported by the large land area. However, if it is not managed properly, it will not be able to produce optimal productivity which then becomes a challenge for Indonesia to improve its natural rubber, one of the way that can be done is rejuvenating plants by replacing old plants with new clones so that the quality will be better. Thus far, the low quality has made the price of Indonesian natural rubber cheap. Therefore, it is hoped that both the government and farming community can improve this. So that in the future Indonesia can continue to compete with other producers in terms of natural rubber exports.

\section{b. Practical Contribution}

Rubber prices tend to fluctuate affecting the amount of rubber exports. The existence of a domestic rubber industry can help absorb non-exported rubber caused by price changes. Not only that, the development of the downstream rubber industry will increase exports of processed products that can generate greater foreign exchange and reduce fluctuations in prices for primary commodities, namely natural rubber and prevent a decline in exchange rates, as well as anticipation of the saturation of the natural rubber commodity market in the future. The government and industrial entrepreneur must work together in efforts to develop the downstream rubber industry which requires various supports such as financing, technology, infrastructure and licensing. It is important to prioritize the sustainability of natural rubber due to the it is a national strategic commodity. In Indonesia, it is also necessary to maintain the sustainability of natural rubber in accordance with local conditions. Therefore, the government is expected to be able to combine the sustainability of international natural 
rubber with Indonesian conditions. The goal of natural rubber sustainability is the welfare of farmers while protecting the environment.

\section{Conclusion}

\subsection{Conclusion}

Based on the research results, it shows that Indonesia has a stronger competitiveness than Thailand in the world market through the results of Indonesia's RCA index value which is higher, 30.2 than Thailand 28.6. As Indonesia being higher by 1.6 points, it gives hope for Indonesia to keep continue increasing production in the coming year by optimizing land use and increasing productivity by means of plant rejuvenation. The greater supply of Indonesian natural rubber to the United States as the main destination country makes Indonesia has stronger competitiveness, with an RCA index value of 80.3 compared to Thailand with a value of 18.2. Whereas Thailand's natural rubber exports have stronger competitiveness with an RCA index value of 36.4 compared to Indonesia, 16.5 in the Chinese market, which is the main export destination country for Thai natural rubber. The lack of Indonesian natural rubber exports to China is due to the low quality of Indonesian natural rubber, consequenlty there has to be efforts will be made to improve this quality by using superior clones and maximum management. The results of the calculation of the value of Indonesian and Thai ISPs for natural rubber commodities in the world market, the United States market and the Chinese market are positive, so in these three markets the two countries have a competitive advantage and have a role as exporters in the 2004-2018 period.

\subsection{Suggestion}

The suggestion that can be given regarding this research is that it is hoped that the government will continue to pay more attention to the natural rubber commodity. Related to production volume, productivity, product quality, and product differentiation made from natural rubber so that these advantages can continue to increase. Serious handling is also expected to be carried out not only by the government, but also by the farming community, industrial entrepreneurs, and exporters. The development of natural rubber competitiveness must be continuously improved and focused on a number of product standard requirements set by importing countries such as product standardization, packaging, labeling, and origin marking, so that the export commodity is not inferior to other competitors. For further researchers, they can continue their research by analyzing the strategies needed to increase the excellence of Indonesia's natural rubber exports in order to continue to compete in international markets as well as in markets of major destination countries.

\section{References}

Badan Penelitian dan Pengembangan Pertanian (Litbang). 2007. Inovasi Teknologi Pertanian. Kementerian Pertanian. Jakarta.

Badan Pusat Statistik. 2019. Statistik Karet Indonesia. BPS RI. Jakarta.

Balassa, Bela. 1961. The Theory of Economic Integration. Richard D. Irwin. Inc. Homewood. Choiruddin, M, A, 2018. Analisis Daya Saing Ekspor Karet Indonesia. Malaysia dan Thailand Ke Pasar Amerika Serikat Periode 2005-2015. Fakultas Ekonomi Dan Bisnis Universitas Muhammadiyah. Surakarta.

CNBC. 2019. https://www.cnnindonesia.com/ekonomi/. (Accessed on 27th of June 2020.).

Food and Agliculture Organisation (FAO). 2019. Food and Agliculture Commodities Production. www.faostat.org (accessed on 15th December 2019). 
Harahap, Nurichsan H. P. dan Bhima Agung S. 2018. Analisis Daya Saing Komoditas Karet Alam Indonesia ke Pasar Global. Jurnal Transborders. Vol. 1 No. 2.

Julivanto, Vagha. 2009. Dinamika Ekspor Karet Alam Indonesia. Skripsi. Departemen Ilmu Ekonomi Fakultas Ekonomi Dan Manajemen. Institut Pertanian Bogor.

Kusdriana, D. 2009. Dinamika Agribisnis dan Industri Karet Indonesia dalam Persaingan Global. PT Media Data Riset. Jakarta.

Permatasari, I G Ayu Ika dan Surya Dewi Rustariyuni. 2015. Analisis Daya Saing Ekspor Biji Kakao Indonesia Di Kawasan ASEAN Periode 2003-2012. E-Jurnal EP Unud. Vol. 4. No.7.

Perdana, Resti Puspa. 2019. Kinerja Ekonomi Karet dan Strategi Pengembangan Hilirisasinya di Indonesia. Jurnal Forum penelitian agro ekonomi.Vol. 37 No 1.

Ragimun. 2017. Analisis Daya Saing Karet dan Produk dari Karet di Indonesia Terhadap Cina. Peneliti pada Pusat Kebijakan Ekonomi Makro.Badan Kebijakan Fiskan Kemkeu

Radityo Ihsan, Rini Dwiastuti dan Abdul Wahib Muhaimi. 2014. Daya Saing Karet Alam Indonesia Di Pasar Dunia. Jurnal. Vol. XXV. No. 3

Rochmat, Ismiati Marfu'ah, Darsono dan Erlyna Wida Riptanti. 2017. Analisis Daya Saing Ekspor Komoditas Karet Alam Provinsi Jawa Tengah. Journal of Sustainable Agriculture. Vol. 32. No. 2

Rubber Research Institute of Thailand. 2019. Thailand Natural Rubber Statistic. www.rubberthai.com (accessed on 17th of December 2019)

Rubber Statistical Bulletin. 2018. Statistical Summary of World Rubber Situation. http://www.rubberstudy.com/publications.aspx (acceseed on 27th June 2020)

Sinaga, Meliyora Nova. 2011. Analisis Faktor-Faktor yang Mempengaruhi Ekspor Karet Alam Negara Thailand, Indonesia, dan Malaysia. Skripsi. Departemen Agribisnis, Fakultas Ekonomi dan Manajemen, Institut Pertanian Bogor.

Syahputra, R, Yogi, Suardi Tarumun dan Jumatri Yusri. 2014. Analisis Daya Saing Ekspor Karet Alam (Natural Rubber) Indonesia di Pasar Internasional. Jurnal. Vol.1. No.2

Tambunan, T. T. H. 2001. Perkembangan Sektor Pertanian di Indonesia. Beberapa Isu Penting. Ghalia Indonesia. Jakarta.

Thailand Investment Review. 2016. Thailand: The World's Leader in Natural Rubber Production. vol. 26 no. 8. https://www.boi.go.th (accessed on 16th Meay 2020)

Trade Map. 2019. http://www.trademap.org/ (accessed on 14th December 2019).

UN Comtrade. 2019. https://comtrade.un.org/ (accessed on 14th December 2019).

Widyantari, I. 2013. Daya Saing Ekspor Komoditas Kelapa Indonesia. SEPA.Vol.10. No. 1 